\title{
Night-guards: Exploring gain and losses
}

\author{
Aboke Simisola Janet ${ }^{1}$, Ajegbomogu, J.0 ${ }^{2}$, Micah Damilola John ${ }^{3 *}$ \\ ${ }^{1}$ Oyo State College of Agriculture, Igbo-Ora, Nigeria \\ 2, 3 Adekunle Ajasin University, Akungba-Akoko, Nigeria
}

\author{
Keywords \\ Night-guards \\ Community policing \\ Crime \\ Routine activity \\ Rational choice
}

Received: 7 September 2019

Accepted: 9 November 2019

Published: 12 March 2020

\begin{abstract}
The study examined the perception of crime management's pattern adopted by nightguards and the relationship with the conventional police system. Routine activity theory provided a guide for the study. The study design was descriptive and qualitative, along with multistage sampling. Questionnaire and in-depth interviews were used for data collection. A total of 150 copies of the questionnaire were valid for data analysis, while 19 respondents were interviewed. Hence, $76 \%$ of the respondents were impressive and satisfied with the operation of nightguards in crime control. Though $10 \%$ of the respondents expressed some reservations against the services of Guards, there was a strong desire among $64 \%$ on the need for additional Guard personnel to combat crime challenges. There was a cordial relationship between the Police and nightguards. Nevertheless, a gap in terms of regular acquaintance with nightguards was the area of concern. While $79 \%$ identified regular funding as a major challenge confronting the effective operation of Guards in crime control, arbitrary use of force by Night-guards resulting in human rights violation was the major concern of the resident community. The study held that the role of nightguards in crime control is complementary, especially when assessed in terms of community protection and safety. The government should give nightguards recognition through training and funding to buttress the crime control system.
\end{abstract}

(C) 2020 The Author(s). Published by TAF Publishing

\section{INTRODUCTION}

The problem of crime in the Nigeria society especially in the urban centres has assumed a wider dimension to the extent that the Criminal Justice System (CJS) such as courts, the police and prisons could no longer cope with the problems of crimes and criminal activities in our society. Globally, every five years, $60 \%$ of city inhabitants have been victims of one form of crime or the other and over half of these crimes have involved property. Violent crimes such as murder, infanticide, assault, rape, sexual abuse, acts of terrorism, buying and selling of women and children constitute another 25 to 30 percent of urban crime (Agbola, 1997; Yildiz, 2015).

In Nigeria, the crime rates are on the increase and have posed a serious threat to human lives and property. The police, the court and prisons as law enforcement agencies alone could no longer tackle the myriad of social problems confronting the people. Generally, there is insecurity of lives and property and people are no longer safe neither could they sleep with their two eyes close (Okunola, 1997). There is fear and uncertainty in the mind of people. Insecurity of lives and property abounds every where such that an atmosphere of fear pervades everywhere in the country both the rural and urban centres. According to Kaplan and Kaplan (1978), fear is an emotional reaction to danger. Agbola (1997) also argues that the response to fear is to begin to look for ways of mitigating the incidence of crime and funding protection from it. Therefore, the need to tackle these problems calls for urgent action. Hence, the use of the traditional methods of social control such as the hiring of NightGuards to complement the role of the police becomes imperative.

The problem of insecurity of lives and property, armed robbery, kidnapping are on the increase and the police alone seems to be unable to cope with these challenges (Agbola, 1997). These challenges are no doubt enormous and for the police to surmount, it needs the cooperation of the cit-

\footnotetext{
* corresponding author: Micah Damilola John

†email: damilolamicah@yahoo.com
} 
izens in carrying out its statutory functions of enforcement of laws and arrest of criminals. Cursory observation and daily news reports show that most crimes involving loss of life and property in Nigeria are committed within residential housing units (Agbola, 1997). The need to tackle these social problems requires the search for an alternative method of crime control in addition to the CJS which is the formal method of crime control to combat the menace and reduce the prevalence of crime to the bearest minimum. Towards the realization of the need to address the myriad of social problems associated with crime and criminal activities especially in the urban areas, some Landlord Associations have evolved a strategy to complement the efforts of the police in crime control and prevention with the introduction of Community Night-Guards.

According to Okunola (1997), it is against this background of rising crime rate especially violent crime and the perceived ineffectiveness of the Nigeria police force that the emergence of Night Guarding as a phenomenon becomes inevitable. There are many cases of murder, burglary, armed robbery, kidnapping and other social vices which have remained largely unresolved by the police, which have called to question the ability of police to put the problem under control. Therefore, for social order to exist in society there is need for social cohesion and harmony to exist between the people of such society. Violence and crime are a threat to public safety. They cause great personal suffering, material damage and great burden on the urban social network.

\section{Statement of the Problem}

According to Igbo (2006), crime and criminals constitute social problem for the society. The society suffers by loosing quite a lot through direct and indirect impact of crime. To him, the costs of crime to society include social, psychological and economic costs. Crime abounds in every society and it has devastating effect on human lives. There is widespread reign of terrors in our cities and the idea of neighborhood, which stresses cooperation and being one's brother's keepers has been eroded. People no longer trust each other because of the fear of unknown and insecurity that pervades the entire family.

The existing gaps arising from the low level of operation and performance of the modern CJS, especially the police, which fails to satisfy the yearnings and aspirations of people in the security of their lives and property necessitated the people of a community to devise an informal methods of social control such as the introduction of Night-Guards to reduce the menace of crime in their areas or domain. It must be noted that limited research has been conducted in this area and yet there are pertinent questions to be answered such as the strategy being adopted by the people of the community in crime control, the effectiveness of the measures being adopted are of interests and central to this study. This is the gap the research intends to fill.

\section{Objectives of the Study}

The general objective of this study is to evaluate the role of Night Guarding in crime control and prevention. The specific objectives are to:

1 Examine the methods used by Night-Guards in crime control.

2 Identify problems encountered by Night-Guards in crime control.

3 Appraise the attitude of members of the community towards Night-Guards as a means of crime control.

\section{LITERATURE REVIEW AND THEORETICAL FRAME- WORK}

\section{Literature Review}

The word vigilante is of Spanish origin and means "watchman or guard" but its Latin root is vigil which means "awake" or observant. When it is said that someone is taking the law into their own hands, this usually means that they are engaging in vigilante activity or vigilantism. Everyone seems to have an opinion about what vigilantism is but few people have taken the trouble to define it (Johnston, 1996). French (2001) equate vigilante with vengeance. According to him, vigilantism, being the righting of a criminal wrong by wrongful means. The origin of vigilante in American's vigilante tradition is to tie it to something like capital punishment (Azhani, Yusmarwati, \& Pua, 2015; Zimring, 2004).

A review of literature suggests that there is a good deal of consensus in the fact that vigilantism and a vigilante tradition exist but there also appears to be no adequate theoretical framework from which to analyze the phenomenon in systematic fashion. Political scientists (Gatpandan \& Ambat, 2017; Rosenbaum \& Sedberg, 1976) and Psychologists (Marx \& Archer, 1976) have serious disagreements over the definition of vigilantism. Political scientists have categorized it as a subtype of political violence (i.e., establishment violence) and would treat groups such as the $\mathrm{Ku}$ Klux Klan as vigilantes. Psychologists as well as some criminologists are much more likely to consider the vigilante's noble motive and premeditation toward curbing evil as important, making it the ultimate act of good citizenship (i.e., autonomous citizenship). Culberson (1990) also points out the importance of distinguishing between do- 
mestic terrorism, which seeks to harm social order, and vigilantism which seeks to help the social order (i.e, popular sovereignty). The notion vigilante as good citizen appears to have some currency in literature. Vigilante violence is the opposite of revolutionary violence as vigilantism always seeks to restore order or preserve the status quo. Sometimes, it is often said that vigilantism is always conservative, what keeps them united is their common interest in the sometimes necessary use of force or extreme measures in the hands of private citizens.

According to Johnston (1996), there are two kinds of established vigilante groups, crime control vigilantes and social control vigilantes. The crime control vigilante group seeks to punish those whom they believe are factually guilty of criminal wrongs and are likely to escape from justice (e.g., thieves, outlaws, and fugitives). The social control vigilante group seeks to repair some transgression in the social order that threatens to affect the communal quality of life, values or sense of honor (e.g., illegal immigrants), taking jobs away from average workers, ethnic males who threaten to seduce wives and daughters away, anything to make one's children run away. The crime control group is usually caught up in a retaliation cycle at the local level whenever they perceive an act of injustice to occur. The current trend is that it appears that vigilante activities is assuming a low level of operations and being taken over by Community Night-Guards operations and private security Guards in some urban centers in this country.

\section{Marcus Felson's And Lawrence Cohen's Routine Activity Theory}

Routine activity theory says that crime is normal and depends on the opportunities available. If a target is not protected enough, and if the reward is worth it, crime will happen. Crime does not need hardened offenders, superpredators, convicted felons or wicked people. Crime just needs an opportunity (Campbell, 2000). The basic premise of routine activity theory is that most crimes are petty theft and unreported to the police. Crime is not spectacular or dramatic. It is mundane and happens all the time (Giddens, Appelbaum, \& Duneier, 2006).

Another premise is that crime is relatively unaffected by social causes such as poverty, inequality, unemployment. For instance, after World War II, the economy of Western countries was booming and the Welfare states were expanding. During that time, crime rose significantly (Campbell, 2000). According to Giddens et al. (2006), this is because the prosperity of contemporary society offers so much opportunities of crime: there is much more to steal. Hence, the the- ory states that for a crime to occur three elements must be present, i.e., there must be:

- An available and suitable target

- A motivated offender

- No authority figure to prevent the crime from happening. The emphasis of the routine activities theory is to demonstrate the cause of crime in the neighbourhood community. This relied upon the calculated action of the offenders and the loose attitude of capable guardian to protect such criminal ventures. The call therefore is to prevent every available opportunity that may be exploited by criminals. This will be the need for effective Night Guard and Police-Public relation.

\section{RESEARCH METHODOLOGY}

\section{Research Design}

The study adopted descriptive research design and cross sectional study. This combined qualitative and quantitative methods.

\section{Brief Historical Background of Ibadan}

The city of Ibadan is predominantly a Yoruba speaking community in the South Western region of Nigeria. The approximate population is 2.8 million (Marenin, 1985). Ibadan is a composition of different ethnic groups resident in the city thereby making it a multi-ethnic area. The educational development of the area cannot be over emphasized as the first Nigerian Premier University education university of Ibadan is located in the area. The university has since its establishment in 1948 contributed considerably to the socioeconomic development of Nigeria. Moreover, Ibadan is predominantly a composition of Christian worshipers, though Islamic religion also thrives in the area. There are eleven local councils in Ibadan, comprising main city (urban) and less city areas. The less city areas are the transitional, developing centres, though they are not as complex and industrially concentrated as the main city centres. Hence, AboOluwa community in Apete, which is the study area, is classified as 'less city'.

Moreover, Abo-Oluwa community in Apete is made up of people of different ethnic groups, diverse background and cultures. The Yoruba, Igbo and few Hausa settle in the area. The population of Apete in 2006 census is put at 10.000 people, though significant changes may have occurred due to factor of birth and death. The inhabitants of the community comprise adults (men and women), youths, students and children. The community operates under the aegis of the Landlord Associations for each zone. Abo-Oluwa Community is Located in Apete - a sub-urban center within Ibadan 
metropolis.

\section{Study Population}

The population of the study comprises mainly the opinion leaders; chairmen and secretaries of landlord associations, Night-Guards; and community residents. Also included in the population are Landlords and Police officers.

\section{Sample Size and Sampling Technique}

According to Palmiotto (1999), Ibadan city is put at 2.8 million resident people. The findings relied on the following formula for sample size as indicated in the work of Merton and Merton (1968).

$$
S S=\frac{Z^{2}[P(1-p)]}{D^{2}}
$$

SS $=$ Sample size

$Z=$ Level of significance (1.96)

$P=$ the estimated proportion of the factor to be studied in the population ( $50 \%$ or 0.5 ).

$D=$ sampling error that can be tolerated $(0.05 \%)$

Therefore:

$$
\frac{1.96^{2}[0.5(1-0.5)]}{0.05^{2}}
$$

$\mathrm{SS}=384.16$.

Approximate sample size $=384$.

Since the estimated proportion of factor studied is $50 \%$, the sample size is limited to 192 . The selection of respondents for the sample was based on simple random technique. This is because every respondent was given equal chance to fill a copy of questionnaire soliciting their opinions. Hence, for questionnaire instrument, sixty four (64) respondents were each selected randomly from study locations, which comprised Papa Laogun, Papa Alafia and Olorunshogo, though 150 copies of the questionnaire were valid for data analysis. It is important to state that researcher did not have access to sample frame that would have provided a guide for selection of sample, however the number of respondents selected based on simple random (balloting) was reasonable to make empirical generalization from the study areas. Further, 19 in-depth interviews based on purposive method were conducted. Hence, two Night-guards were selected from each location, while one (1) senior police officer and 12 resident members were subject to reasonable discussion. Therefore, a total of 211 sample of respondents was selected, which combined both questionnaire and in-depth interviews.

\section{Instruments and Methods of Data Collection}

The method of data collection is both quantitative and qualitative. Questionnaire was used to collect quantitative data and in-depth interviews were used for qualitative data. The questionnaire was operationalised into sub-sections which covered the study objectives. Thus, the structure of the questionnaire was largely based on closed ended questions with options, though there were few open ended questions that allowed for expression of opinions. Interview was inclusive because of the need to appraise divergence of opinions and cover issues that may be insufficient for survey data. Data was collected intermittently across the three locations (Papa Laogun, Papa Alafia and Olorunshogo). The researcher covered the study areas one after the other to sustain efficiency of responses.

\section{Methods of Data Analysis}

The data collected were analyzed with electronic software called Statistical Package for Social Sciences (SPSS) version 17.0.

\section{Ethical Consideration}

In the field work, the consent of respondents was sought before information was solicited. This means none of the respondents was subjected to threat or under duress for whatever information supplied.

\section{DATA ANALYSIS AND DISCUSSION Demographic Data Analysis}

The importance of demographic data cannot be overemphasized in any data analysis. It tends to influence and shape responses to substantive issues in research questions. In this light, the consideration of demographic data becomes increasingly significant.

Table 1 shows the respondents' age distribution. The percentage distribution shows that the highest proportions of respondents $56.7 \%$ were between the age group of 50 years and above, while $23.3 \%$ was within the age group of $41-50$ years. Only $12.0 \%$ of the respondents were in age bracket 31-40 years. This implies that most of the resident respondents were adult. The findings also revealed that $70.0 \%$ of the respondents were male while $30.0 \%$ of the respondents were female. The large proportion of male participation could be due to the fact that most of them were landlords as very few women owned houses in the study community. The findings indicated that $82.0 \%$ of the respondents were married while $18.0 \%$ of the respondents were single. This means most of the respondents were parents and with their families. 
TABLE 1. Distribution of Respondents According to Socio-economic Demographic Variables

\begin{tabular}{|c|c|c|}
\hline Variables Frequency & Percentage & \\
\hline Age & Frequency & Percentage \\
\hline $20-30$ & 12 & 8 \\
\hline $31-40$ & 18 & 12 \\
\hline $41-50$ & 35 & 23.3 \\
\hline 50 and above & 85 & 56.7 \\
\hline Total & 150 & 100.0 \\
\hline Sex & Frequency & Percentage \\
\hline Female & 45 & 30 \\
\hline Male & 105 & 70 \\
\hline Total & 150 & 100.0 \\
\hline Marital Status & Frequency & Percentage \\
\hline Single & 12 & 8.0 \\
\hline Married & 123 & 82.0 \\
\hline Widow & 5 & 3.3 \\
\hline Divorced & 10 & 6.7 \\
\hline Total & 150 & 100 \\
\hline Educational Level & Frequency & Percentage \\
\hline Primary & 12 & 8.0 \\
\hline Secondary & 18 & 12.0 \\
\hline NCE/OND & 56 & 37.3 \\
\hline HND/Degree & 40 & 26.7 \\
\hline Postgraduate & 15 & 10.0 \\
\hline None of the above & 9 & 6.0 \\
\hline Total & 150 & 100.0 \\
\hline Occupation & Frequency & Percentage \\
\hline Trading & 40 & 26.7 \\
\hline Civil servant & 76 & 50.6 \\
\hline Farmer & 24 & 16.0 \\
\hline Technician & 10 & 6.7 \\
\hline Total & 150 & 100.0 \\
\hline Religion & Frequency & Percentage \\
\hline Christianity & 85 & 56.7 \\
\hline Islam & 60 & 40.0 \\
\hline Traditional & 5 & 3.3 \\
\hline Total & 150 & 100.0 \\
\hline Number of children & Frequency & Percentage \\
\hline One & 26 & 17.3 \\
\hline Two & 40 & 26.7 \\
\hline three and above & 84 & 56.0 \\
\hline Total & 150 & 100.0 \\
\hline Income & Frequency & Percentage \\
\hline $21000-50000$ & 24 & 16.0 \\
\hline $51000-70000$ & 90 & 60.0 \\
\hline $71000-100000$ & 21 & 14.0 \\
\hline 100000 \& above & 15 & 10.0 \\
\hline Total & 150 & 100.0 \\
\hline
\end{tabular}

Nigeria has a four-tiered educational system known as the 6-3-3-4 system. Free education is compulsory up to the Junior Secondary School. Distribution of the respondents by level of education shows that $37.3 \%$ of the surveyed population had NCE/OND education as shown in the table; about $26.7 \%$ had HND/Degree education, $12.0 \%$ had secondary education, while only $10.0 \%$ had post graduate education. The level of education an individual obtains has positive impact on their occupation, income, chances of marriage, the quality of life and that of their children.
A consideration of the occupation of the respondents revealed that $56.7 \%$ of the total respondents were civil servant (lecturer, teacher, ministry workers), while $26.7 \%$ of the respondents were in the business of buying and selling which was categorized as trading in the study. The table further indicates that $16.0 \%$ of the respondents in the study area were farmers, while $6.7 \%$ of the respondents were Technicians. This implies that the majority of people living in the community were civil servants, who in day time were not always around. This accounted for the day time 
burglary and theft that were common in the community. The income level of the respondents shows a similar trend with the occupation. The table reveals that $60.0 \%$ of the respondents earned N51000- N70000 per month, 16.0\% of the respondents earned between N21000 and N50000 per month, while $14.0 \%$ and $10.0 \%$ of the total respondents earned between N71000 and N100000 per month and above N100000 per month respectively. This implies that majority of the respondents earned between N51000 and N70000 per month in the study area. The level of income implies a relatively faire standard of living because life chances is dependent upon economic resources.

Moreover, the analysis shows percentage distribution of respondents according to their religious affiliation. Religion is one of the factors that influences the attitude and societal belief on sensitive issues, such as crime. Religious belief plays vital role in crime control. Thus, $56.7 \%$ of respondents were Christians while $40.0 \%$ were Muslim, only 3.3\% of the respondents were traditional religion worshippers. The study also revealed that $56.0 \%$ of the respondents had three and above children in the family while $26.7 \%$ of the respondents claimed to have two children. Only $17.3 \%$ of the respondents had one child in their family. This implies that families with more than three children are the majority in the study area.

\section{Appraisal of the Methods used by Night-guards in Crime Control}

This objective sought to know the pattern adopted in the informal method of crime control. Although much is known about the conventional, orthodox (Police) method of crime control, it becomes significant to gain insight into the operation of Night-guards in Abo-Oluwa resident community. In light of this, respondents expressed their views thus:

Night-guards performance is satisfactory. They use whistle to alert people; stick, horse whip. Iron gate to barricade entrance; restrict movement between 11pm - 5am (IDI/Tenant/Papa Laogun/March 2011).

Moreover, a respondent said:

Night-Guards barricade the street. When new residents/landlords join the community, each is made to swear to an oath that he/she will not commit crime in the community (IDI/Papa Alafia/March 2011).

It is important that this factor swearing to oath is critically analyzed. To start with, what is the morality supporting the basis of oath? Does this support the cultural diversity held by heterogeneous resident tenants/landlords? Or what is the religious basis for swearing an oath? It follows that whoever resists the oath responsibility becomes suspicious of act subversive of the collective conscience and consensus of the community. Though such measure may serve to check and balance social behavior of residents, it may not be morally justified, if people are compelled against their norms and values in terms of religious faith. Further in this analysis, some respondents expressed their opinions.

Guards have arrested thieves in the pasts. They have whistle, guns; they operate from 12 midnight to $5 \mathrm{am}$ on daily basis. They apprehend criminals and hand them over to the Police after thorough beating (IDI/ Guard/Papa Alafia/March 2011).

In addition, a tenant resident said:

Guards have traditional charms. They use incantations to defend self against any attack. They called black power. They patrol at night between $12 \mathrm{am}$ to $5 \mathrm{am}$. Some Guards have no guns but stick, torch light and whistle to operate (IDI/Guard/Papa Laogun/ March 2011).

Again, charms and incantations were reported in the operation of Guards. It becomes imperative to enquire the relationship of traditional charm to security control measure in the study community. Do the charms facilitate effectiveness in the service of Night-guards? This opens a new area of investigation in the sociological analysis of Night-guards. However, it is obvious that some Guards do not have gun to arm themselves in the course of their service. What should be known is that if a person does not have training skills about the use of ammunition, then there is no reason for having or using it. This leads us to ask the question of education among Guards. If there is knowledge and training, it means that use should not be hindered. Since indications in the study area showed effectiveness of the informal measure (Night-guarding), to sustain the trend will be to reinforce the system in terms of arms and remuneration. However, such practice must be under guise of established laws and licenses.

\section{Problems Encountered by Night-Guards in Crime Con- trol}

Dimensions of problems encountered by Night-guards were revealed in the series of interviews conducted. This is rightly put by respondents:

The number of Night-guards in this community is just three. This is a large area. Eight Guards are not even enough. Each landlord contributes \#400 per month which is not enough (IDI/Guard/Papa Laogun/March 2011).

As succinctly put by another discussant:

Night-guards are employed to cover area larger than what they can cover. The problem is not coverage per se; it is the issue of money and salary (IDI/Guard/Papa Alafia/March 
2011).

In addition, a respondent said:

Night-guard is more expensive. Police is supposed to provide free services to the community. Because of shortage of personnel in the Police, they can not cover the entire community at once (source: interview; resident, Papa Laogun, March 2011).

Therefore, it can be stressed that Night-guards are faced with shortage of personnel to cover wide area of community landscape in the study area. Though the services of the informal security group are attested to be effective, there seemed to be financial constraint that threatened its existence. It is obvious that Police duty is to protect lives and property including community household security. Thus, by reason of Police limited coverage, alternative security measure was established, that is, Vigilante guards. It follows that should financial liability of the informal system be left only in the hands of resident community, it may be difficult to sustain the existence of Night-guards for community security.

The picture of the problem is further demonstrated in the word of a respondent.

Guards use to meet fetish things, evil spirit at night. There are no kits to ward off cold in the mid night. Some Guards sleep off because of too much cold (IDI/Guard/Olorunshogo/March 2011).

The dimension expressed in the above view could probably explain the reason for use of local charms as a protection. For example, if Guards do encounter fetish and evil spirit at night, then there must be means of safety and protection such as traditional charm or black power also called juju.

\section{Attitude of Members of the Community towards Night- Guards as a Means of Crime Control}

Dimensions of attitudes and feelings of respondents were expressed on the services of Night-guards in the study area. Though these attitudes have been evaluated in the preceding frequency and percentage distributions, it is important to examine the in-depth analysis of the opinions. As put in the words of a male respondent:

People's attitude to Nigh-guards is good, they perform to expectation. Government should give proper approval so that they can operate without being harassed and arrested by the police (IDI/Tenant/Papa Laogun/March 2011).

This is a positive praise of the informal system of crime control. Other respondents submitted thus:

Landlords association should assist Night-guards to solicit the absorption into one of the security outfit of government. Guards should be given local training; give them license to carry gun and adequate remuneration (IDI/Landlord/Papa Alafia, March 2011).

Furthermore, a respondent said:

Guards should be employed with weapons. Acquire strategic knowledge, trained on how to combat crime, how to handle weapons. Landlords association should pay their salaries as at when due to keep them more effective (IDI/Tenant/Olorunshogo, March 2011).

The consensus opinion in the study area is the way forward to improve the services of Night-guards. This is rather antithesis to views expressed in the literatures for the abolition of the informal system (Campbell, 2000). Some would qualify Guards as group of mobs, killers, robbers, and thugs to mention a few. This was proved invalid among the respondents. Though Night-guards may not be completely absolved of illegality, what is important is to regulate the system rather than abolition, since it is shown to be effective in community crime control. However, a mixed feeling was expressed by some respondents:

Large proportions of Guards are not known to the police. They are law breaker because once you not do respect human right; the police will treat you as threat to order. The police arrest Guards who are found guilty of human rights abuse (IDI/Police officer/March 2011).

As put in the words of another respondent:

Some Night-guards do abandon their duty at nights. They pretend to be on duty, yet slept off without responsibility (IDI/Landlord/Papa Laogun/March 2011).

It is important to mention that though police service could be better in crime control, however, do police services cover community surveillance especially in the dead of night? Yet, this is part of police role. What is important therefore, is complementarities in security services rather than abolition of one for another. After all, there is cordiality between the two in terms of handing over criminals to the Police. Hence, police-public relation and familiarity with serving Guards should be promoted for adequate crime control.

\section{CONCLUSION}

The study revealed a great deal of information about the nature of operation adopted by Night-guards in crime control in the study areas. Although some preceding literatures may have demonstrated Night guarding in negative and awkward look (Sesay, 2003), it is apparent that the role of this informal crime control is essential and indispensable to fight crime, especially in the study area. To conclude, therefore, the study holds that people who are involved in night guarding or its activities cannot be condemned wholesomely. This is because empirical fact shows that the infor- 
mal activity is very effective and functional in crime control. Since time varies and societies differ in culture and value, it is difficult to socially accept a condition of the past for the present. Though studies may have found critical evidence to condemn the role of night guarding in crime control, the crucial project of criminology should be to research way of improving and enhancing services of Night-guards for effective operation in neighborhood policing.

\section{LIMITATIONS AND RECOMMENDATIONS}

This study has some potential limitations, and researchers are encouraged to investigate further the role and significance of night guards in future.

Consequent upon empirical data analysis and interpretation in the study, the following recommendations are generated:

1. The role of Night-guards in the community should cover not only security at night but also provide for protection of properties in the day period. This is because criminal act such as burglary in the neighborhood community tends to thrive in day light when resident members might have departed for their respective locations of occupation. Though to finance the service extension may be difficult, community members should solicit funding from either government or private organization.

2. Nigh-guards should be encouraged in every community to complement the role of the police in crime control. To sustain the role of the Night-guard therefore, government and other private hand should supplement financial resource of the community in prompt payment of salaries to Guards.

3. The current level of police public relations should be intensified to accommodate other members of informal groups that are stakeholders in security and crime control concern. This is necessary to ensure acquaintance.

4. There should be legislation that will authorize Nightguards to carry sophisticated guns for purpose of crime control in the neighborhood. This should however be under strict license.

5. There should be adequate funding for Night-guard invested in the acquisition of sport kits such as cold protection wears, bullet proof, sport canvass, Global System for Mobile (GSM) for effective communication and so on. This will help to overcome the problem of night cold and other possible challenge that may confront health and effective operation. In essence, the provision of funding should not be left as the exclusive liability of resident community.

\section{REFERENCES}

Agbola, T. (1997). The architecture offear: Urban design and construction response to urban violence in Lagos, Nigeria. Ibadan, Nigeria: Ifra.

Azhani, C. I., Yusmarwati, Y., \& Pua, P. K. (2015). The importance of balanced diet to the human capital formation on physical and mental fitness. International Journal of Humanities, Arts and Social Sciences, 1(3), 114-118. doi:https://doi.org/ 10.20469/ijhss.20001-3

Campbell, B. B. (2000). Death squads: Definition, problems, and historical context. In Death squads in global perspective. New York, NY: Springer.

Culberson, W. C. (1990). Vigilantism: Political history of private power in America (No. 28). California, CA: Greenwood Publishing Group.

French, P. A. (2001). The virtues of vengeance. Kansas, KS: Lawrence University Press.

Gatpandan, M. P., \& Ambat, S. C. (2017). Mining crime instance records of Philippine National Police District Vi Province of Cavite, Philippines: An exploratory study to enhance crime prevention programs. Journal of Advanced Research in Social Sciences and Humanities, 2(4), 176-187. doi:https://doi.org/10.26500/jarssh-02-2017-0303

Giddens, A., Appelbaum, R. P., \& Duneier, M. (2006). Essentials of sociology. New York, NY: Norton.

Igbo, E. (2006). Criminology: A basic introduction. New York, NY: Jock-Ken Publishers.

Johnston, L. (1996). What is vigilantism? The British Journal of Criminology, 36(2), 220-236. doi:https://doi.org/10.1093/ oxfordjournals.bjc.a014083

Kaplan, S., \& Kaplan, R. (1978). Environment for people. In Humans cape. California, CA: Wadsworth.

Marenin, O. (1985). Policing Nigeria: Control and autonomy in the exercise of coercion. African Studies Review, 28(1), 73-93. doi:https://doi.org/10.2307/524568

Marx, G., \& Archer, D. (1976). The urban vigilante. Psychology Today, 2(6), 45-50.

Merton, R. K., \& Merton, R. C. (1968). Social theory and social structure. New York, NY: Simon and Schuster. 
Okunola, R. (1997). Working in the shadow of death: The case of night guards in urban centres in Nigeria. Ibadan, Nigeria: Friedrich Ebert Foundation.

Palmiotto, M. (1999). Community policing: A policing strategy for the 21st century. New York, NY: Jones \& Bartlett Learning. Rosenbaum, H., \& Sedberg, P. (1976). Vigilante politics. Philadelphia, PA: University of Philadelphia Press.

Sesay, M. (2003). Ethnic militias and the future of democracy in nigeria. Ife, Nigeria: Obafemi Awolowo University Press.

Yildiz, . K. G., F. U. (2015). Examining the effects of computer-assisted preschool educational activities on children's intuitive mathematical ability. Journal of Advances in Humanities and Social Sciences, 1(1), 1-8. doi:https://doi.org/10.20474/ jahss1.1.1

Zimring, F. (2004). Vigilante mindset. London, UK: Oxford University Press. 